DOI: $10.36067 /$ jbis.v2i1.33

ISSN: 2685-2543

\title{
Analisis perbandingan resiko keuangan Bank Konvensional dengan Bank Syariah
}

\author{
Alim Setiawan \\ alimsetyawan93@gmail.com \\ Universitas PGRI Yogyakarta \\ Lulu Amalia Nusron \\ Universitas PGRI Yogyakarta \\ lulu.amalia@upy.ac.id
}

\begin{abstract}
This study aims to compare financial risks in conventional banks with Sharia banks in Indonesia in the 2014-2018 period. The research object consisted of 8 banks, namely 4 conventional banks (BNI, BRI, BCA, and Mandiri) and 4 Islamic banks (BNIS, $B R I S, B C A S$, and Mandiri Syariah). The data source is in the form of ratio or secondary data obtained from the IDX web. In the form of the bank's 2014-2018 annual financial statements and collected 20 data. The ratios used include NPL / NPF for credit risk, LDR / FDR for liquidity risk, BOPO for operational risk, and NIM / NOM for market risk. This study uses the independent sample t-test and Mann Whitney test to analyze the hypotheses. Based on the results it was concluded that: 1) there were no differences in credit risk and liquidity risk of conventional banks and Islamic banks 2) there were differences in operational risks and market risks of conventional banks and Islamic banks.
\end{abstract}

Keywords: financial risk; conventional banks; and Islamic banks.

\section{Pendahuluan}

Bank memiliki peran yang sangat penting di suatu negara, yaitu sebagai penggerak perekonomian. Fungsi bank seperti tempat menyimpan uang, melakukan pembayaran dan penagihan (Nainggolan, 2017). Menurut prinsipnya bank yang melakukan kegiatan usahanya di Indonesia yaitu bank konvensional dan bank syariah. Bank syariah berdiri dengan dengan prinsip islam yang melarang adanya bunga dalam setiap transaksi sedangkan bank konvensional setiap kegiatan usahanya menggunakan bunga. Perbedaan mendasar antara bank konvensional dengan bank syariah dapat diketahui dari struktur organisasi, aspek legal, dan perhitungan laba ruginya (Rustam, 2013).

Bank konvensional dan bank syariah bersaing satu sama lain untuk menarik perhatian masyarakat atau calon nasabah dalam hal produk lending maupun funding, fasilitas, dan berbagai layanan lainnya. Persaingan yang ketat antar bank dapat dilihat dari jumlah bank umum yang beroperasi di Indonesia. Berbagai macam kegiatan usaha yang dilakukan oleh bank konvensional maupun bank syariah, tentu tidak luput dari berbagai macam resiko yang akan dihadapi dan berpotensi dampak negatif pada kegiatan usaha tersebut. Menurut Yulianti (2009) dalam konteks perbankan terdapat resiko yang dapat diperkirakan maupun yang tidak, yang dapat berdampak negatif terhadap pendapatan dan permodalan bank. Dalam implementasi sebuah pengelolaan resiko, bank perlu menelaah resiko yang telah terjadi maupun yang akan terjadi secara detail. Adapun sumber resiko yang terjadi dapatberasal dari bank yang bersangkutan maupun afiliasi lainya. Beberapa jenis resiko 
dalam dunia perbankan yaitu resiko kredit, resiko likuiditas, resiko pasar, resiko hukum, resiko operasional, resiko reputasi, resiko strategi, dan resiko kepatuhan.

Data Statistik Perbankan Indonesia per Oktober 2019 menunjukkan terdapat 96 bank umum konvensional dan 14 bank umum syariah dengan total 110 bank umum yang beroperasi di Indonesia. Jumlah tersebut menurun dari periode sebelumnya, yaitu 101 bank umum konvensional dan 14 bank umum syariah dengan total 115 bank umum per Desember 2018. Menurunnya jumlah bank umum konvensional dibandingkan jumlah bank umum syariah yang stabil menjadi motivasi peneliti apakah terdapat perbedaan resiko yang dihadapi oleh kedua jenis bank tersebut sehingga bank umum konvensional harus menutup kegiatan usahanya untuk menekan segala resiko yang dihadapi. Selain itu, peneliti masih menemukan sejumlah hasil penelitian-penelitian yang tidak konsisten. Putri et al., (2015) menunjukkan hasil bahwa terdapat perbedaan antara bank konvensional dan bank syariah jika dilihat berdasarkan resiko keuangan. Hasil penelitian tersebut didukung oleh Ramlan et al., (2018) yang memberikan hasil penelitian serupa. Namun, lain halnya dengan Lombogia (2015) dan Arinta (2016) yang menyatakan bahwa tidak terdapat perbedaan resiko pada kedua jenis bank tersebut.

\section{Landasan teori dan hipotesis}

\subsection{Pengertian Bank}

Menurut Undang-Undang Republik Indonesia Nomor 10 Tahun 1998 tentang Perbankan bank adalah badan usaha yang menghimpun dana dari masyarakat dalam bentuk simpanan dan menyalurkan kepada masyarakat dalam bentuk kredit dan/atau bentuk-bentuk lainnya dalam rangka meningkatkan taraf hidup rakyat banyak. Sedangkan menurut Lukman (2009) bank merupakan lembaga yang mempunyai izin untuk menghimpun dana dan langsung dijadikan aset untuk kemudian disalurkan kepada masyarakat atau calon nasabah dalam bentuk pinjaman atau modal kerja yang kemudian memberikan keuntungan bunga bagi bank. Secara umum karakteristik lembaga perbankan dapat dipahami sebagai berikut (Taswan, 2017): a) untuk memenuhi kewajiban bank yang harus dibayar maka likuiditas sebuah perusahaan bank harus selalu dijaga dengan baik; b) dilema sebuah perusahaan bank sering terjadi antara meningkatkan empower atau memelihara likuiditas; c) Bank merupakan lembaga yang dipercaya dan memiliki kedudukan strategis dalam meningkatkan pembangunan nasional.

\subsection{Bank Konvensional}

Menurut Undang-undang Nomor 10 Tahun 1998 Bank Konvensional adalah bank yang melaksanakan kegiatan usaha secara konvensional yang dalam kegiatannya memberikan jasa dalam lalu lintas pembayaran. Kegiatan usaha-usaha pada bank konvensional yaitu memberikan pelayanan kepada masyarakat dan nasabah terkait dengan fasilitas yang nasabah minta seperti layanan menabung, deposito dan kemudian bank memutarkan uang dari nasabah untuk keperluan nasabah lain yang ingin mengajukan pinjaman atau kredit berupa modal kerja, kartu kredit yang memiliki layanan kepada bank (Iskandar, 2013). 


\subsection{Bank Syariah}

Pengertian bank syariah yaitu bank yang kegiatan usahanya berdasarkan prinsip syariah islam dan kegiatan usahanya tidak mengandung riba, maisir, gharar, haram, zalim. Bank yang memiliki prinsip syariah harus memastikan proses kegiatan bisnis yang terjadi didalamnya terbebas dari unsur; a) Riba, yaitu adanya pendapatan yang bertambah melebihi pokok pinjaman karena berjalannya waktu, b) maisir; adalah transaksi yang sifatnya tergantung pada keadaan tertentu dan keberuntungan, c) gharar; objek transaksi yang tidak jelas, keberadaanya tidak diketahui, tidak dimiliki, dan tidak dapat diberikan pada transaksi terjadi, d) haram; objek transaksi yang dilarang oleh syariah islam, dan e) zalim; objek transaksi yang terjadi secara tidak adil sehingga merugikan salah satu pihak (Iskandar, 2013).

\subsection{Resiko Kredit}

Resiko kredit adalah resiko yang berhubungan dengan pihak peminjam/ kreditur yang mengalami kerugian sehingga tidak mampu membayarkan kembali dana yang telah dipinjam saat jatuh tempo. Resiko kredit dapat dilihat dari seberapa besar atau seberapa tinggi pembiayaan bermasalah pada suatu bank. Rasio NPL (Non Performing Loan) pada bank konvensional dan rasio NPF (Non Performing Financing) pada bank syariah digunakan untuk menilai persentase jumlah kredit bermasalah terhadap total kredit yang dikeluarkan oleh bank. NPF dan NPL digunakan sebagai indikator untuk mengukur dan mengetahui suatu tingkat kesehatan aset sebuah bank. Selain itu, kedua istilah tersebut juga dapat membantu manajemen bank dalam mengatasi masalah dari timbulnya resiko kredit yang dapat memberikan dampak negatif bagi kesehatan bank itu sendiri. Jika manajemen bank tidak segera menyelesaikan resiko yang timbul dari rasio NPL dan NPF maka akan mengurangi modal suatu bank. Bank Indonesia telah menetapkan batas untuk rasio NPL dan NPF ini yaitu kurang dari 5\%. Jika lebih besar dari 5\% maka bank memiliki resiko kredit yang tinggi dan jika semakin tinggi maka laba bank akan turun, sehingga masyarakat dan calon nasabah harus jeli tentang perbedaan resiko kredit yang ditunjukan dalam rasio NPL (Latumaerissa, 2014). Beberapa penelitian telah dilakukan berterkaitan dengan perbandingan resiko kredit (NPF dan NPL). Putri et al., (2015) memberikan kesimpulan bahwa tidak terdapat perbedaan resiko kredit, namun Arinta (2016) menyatakan bahwa terdapat perbedaan resiko kredit. Berdasarkan uraian diatas, maka hipotesis yang dirumuskan:

$H_{1}$ : Terdapat perbedaan resiko kredit antara bank konvensional dan bank syariah.

\subsection{Resiko Likuiditas}

Rasio FDR (Financing Deposit Ratio) dipakai untuk istilah bank syariah, sedangkan LDR (Loan Deposit Ratio) dipakai untuk istilah pada bank konvensional. Pada bank tidak mengenal istilah loan (hutang), yang ada adalah financing (pembiayaan). Kedua rasio tersebut dapat dijadikan sebagai indikasi tingkat kemampuan sebuah bank dalam menyalurkan dana yang berasal dari masyarakat. Bentuk produk penyaluran dana yang biasa ditawarkan pada nasabah antara lain: tabungan, giro, deposito, sertifikat berjangka. Jika nilai 
FDR dan LDR pada suatu bank tinggi, maka bank meminjamkan seluruh dana yang dimilikinya kepada masyarakat, sehingga bank menjadi relatif tidak likuid, begitu juga sebaliknya. Batas normal nilai FDR dan LDR menurut ketetapan Bank Indonesia tahun 2010 adalah 85\% - $100 \%$. Informasi besarnya nilai FDR dan LDR sangat diperlukan bagi para investor dan nasabah yang akan menitipkan dananya pada bank (Lukman, 2009). Beberapa penelitian telah dilakukan terkait tentang perbedaan resiko likuiditas (FDR dan LDR) pada bank konvensional maupun syariah. Namun hasil yang diperoleh masih belum konsisten. Penelitian Lombogia (2015) menyimpulkan bahwa tidak terdapat perbedaan pada kinerja keuangan yang dinilai menggunakan rasio likuiditas baik pada bank konvensional maupun bank syariah, sedangkan pada penelitian Putri et al., (2015) menyimpulkan terdapat perbedaan pada resiko likuiditas. Berdasarkan uraian diatas, hipotesis dari penelitian ini:

$\mathrm{H}_{2}$ : Terdapat perbedaan resiko likuiditas antara bank konvensional dan bank syariah.

\subsection{Resiko operasional}

Resiko operasional sering digunakan untuk melihat apakah bank mampu mengelola dan mengendalikan biaya terhadap pendapatan operasional. Perbandingan antara biaya dan pendapatan operasional bank disebut rasio biaya operasional sehingga kemungkinan suatu bank berada pada kondisi bermasalah semakin kecil. Resiko operasional atau BOPO dalam dunia perbankan mempunyai pengaruh besar dalam mengukur seberapa besar tingkat resiko yang ada pada bank. Manajemen bank harus membandingkan antara jumlah biaya operasional dengan pendapatan operasional yang diperoleh. Istilah BOPO dipakai pada semua jenis bank, baik bank konvensional maupun bank syariah (Lukman, 2009). Beberapa penelitian tentang perbedaan resiko operasional (BOPO) telah dilakukan. Hasil penelitian dari Usman (2003) dan Mawardi (2004) menyatakan dalam perbankan dan industri pada umumnya terjadi hubungan negatif antara biaya operasional dan pendapatan operasional (BOPO) dengan profitabilitas. Putri et al., (2015) menyatakan bahwa terdapat perbedaan resiko operasional (BOPO), sehingga hipotesis yang disusun:

$H_{3}$ : Terdapat perbedaan resiko operasional antara bank konvensional dan bank syariah.

\subsection{Resiko pasar}

Adanya variabel pasar yang berubah seperti suku bunga, mata uang, nilai tukar, harga komoditas dapat mengakibatkan resiko pasar terjadi, sehingga nilai aset yang dimiliki oleh bank dapat menurun. NIM dan NOM keduanya merupakan istilah yang dipakai bank baik itu konvensional dan syariah. Rasio ini menggambarkan tentang resiko kerugian yang timbul akibat pergerakan harga pasar. Indikator NIM dan NOM dapat dihitung dari tingkat suku bunga kredit dan tingkat suku bunga simpanan kemudian dibagi dengan rata-rata aset produktif. Manajemen bank akan menganalisa agar rasio ini tidak berada pada angka negatif, jika itu terjadi dapat dikatakan bahwa tingkat biaya investasi lebih tinggi dari apa yang dihasilkan yang berarti manajemen bank tidak dapat menekan atau meminimalisir resiko pasar dengan baik jika bank mengalami kerugian. Beberapa penelitian tentang perbandingan resiko pasar (NIM dan NOM). Salah satunya adalah Arinta (2016) yang menyimpulkan 
bahwa terdapat perbedaan resiko pasar (NIM dan NOM). Pada penelitian ini hipotesisnya adalah:

\section{H.: Terdapat perbedaan resiko pasar antara bank konvensional dan bank syariah.}

\section{Metode Penelitian}

Penelitian ini adalah penelitian komparatif yang bertujuan untuk mengetahui dan menggambarkan apakah terdapat perbedaan resiko keuangan bank konvensional dan bank syariah. Penelitian ini menggunakan bank yang berprinsip konvensional dan bank yang berprinsip syariah di Indonesia. Teknik pengambilan sampel yaitu purposive sampling dengan kriteria:

a. Bank konvensional dan bank syariah yang terdaftar di Bank Indonesia

b. Bank konvensinal dan bank syariah yang menyajikan laporan keuangan selama lima tahun (2014-2018).

Bank konvensional yang memenuhi kriteria diatas ada empat yaitu Bank BNI, Bank BRI, Bank BCA, Bank Mandiri. Sedangkan sampel bank yang berdiri dengan konsep syariat islam yaitu Bank BNI Syariah, Bank BRI Syariah, Bank BCA Syariah, Bank Mandiri Syariah. Data yang digunakan merupakan data sekunder dimana data tersebut didapatkan dari sumber web resmi IDX yang berupa laporan keuangan tahunan (2014-2018).

Penelitian ini menggunakan 3 jenis teknik analisis data, diantaranya:

\section{a. Analisis Rasio Kuangan}

Variabel yang digunakan dalam penelitian ini adalah resiko kredit, resiko likuiditas, resiko operasional, dan resiko pasar. Resiko-resiko keuangan bank dapat dilihat dari rasio-rasio terkait yang kemudian dapat menjelaskan seperti apa kondisi resiko dalam dunia perbankan. Adapun beberapa rasio-rasio yang dapat menjelaskan dan menggambarkan kondisi suatu bank di antara lain:

1) Resiko kredit. Resiko akibat kegagalan nasabah/pihak lain dalam memenuhi kewajiban kepada bank sesuai dengan perjanjian yang disepakati.

Indikator pengukurannya adalah:

$$
\text { Konvensional: } \quad \text { NPL }=\frac{\text { Pembiayaan bermasalah }}{\text { Total pembiayaan }} \times 100 \%
$$

Syariah: $\quad$ NPF $=\frac{\text { Kredit bermasalah }}{\text { Total pembiayaan }} 100 \%$

2) Resiko likuiditas. Resiko akibat ketidakmampuan bank untuk memenuhi kewajiban jatuh tempo dari sumber pendanaan arus kas dan/ atau aset likuid berkualitas tinggi yang dapat digunakan, tanpa mengganggu aktivitas dan kondisi keuangan bank. Indikator pengukurannya adalah:

\begin{tabular}{ll} 
Konvensional: & LDR $=\frac{\text { Jumlah kredit yang disalurkan }}{\text { Total deposit }} 100 \%$ \\
\hline Syariah: & FDR $=\frac{\text { Jumlah pembiayaan yang disalurkan }}{\text { Total deposit }} 100 \%$
\end{tabular}


3) Resiko operasional. Resiko akibat proses internal yang kurang memadai, kesalahan manusia, kegagalan sistem atau adanya kejadian eksternal yang mempengaruhi operasional bank.

Indikator pengukurannya adalah:

Konvensional \& $\quad$ BOPO = Beban operasional $\times 100 \%$

Syariah Pendapatan operasional

4) Resiko pasar. Resiko kerugian pada posisi keuangan serta pencatatan tagihan dan kewajiban diluar posisi keuangan yang timbul dari pergerakan harga pasar.

Indikator pengukurannya adalah :

Konvensional $\quad$ NIM $=\frac{\text { Pendapatan bunga bersih }}{\text { Rata-rata aktiva produktif }} 100 \%$
Syariah
NOM $=\frac{\text { Pendapatan penyaluran dana setelah bagi hasil }- \text { beban operasi }}{\text { Rata-rata total aset }} 100 \%$

\section{Hasil Penelitian}

\subsection{Analisis Rasio Keuangan}

Jumlah observasi data yang digunakan dalam penelitian ini adalah 40 data yang berasal dari 8 bank, yaitu 4 bank konvensional dan 4 bank syariah dengan periode 5 tahun berturut-turut (Tahun 2014-2018).

Tabel 1: Rata-rata Bank Konvensional Vs Bank Syariah

\begin{tabular}{ccc}
\hline Indikator & Bank Konvensional & Bank Syariah \\
\hline NPL/NPF & 2,08 & 3,03 \\
LDR/FDR & 85,34 & 84,20 \\
BOPO & 67,82 & 92,08 \\
NIM/NOM & 6,56 & 3,62 \\
\hline
\end{tabular}

\section{Resiko Kredit}

Pada tabel diatas, tampak bahwa angka rasio pada NPF pada bank syariah menunjukan ratarata lebih tinggi yaitu 3,03 jika melihat angka rata-rata bank konvensional sebesar 2,08 lebih kecil selisih 0,95. Hal ini menandakan bahwa bank syariah memiliki pembiayaan yang bermasalah lebih tinggi. Beberapa faktor yang mungkin dapat mempengaruhi tingkat resiko kredit pada bank syariah yaitu monitoring reguler yang dilakukan oleh pihak bank pada usaha nasabah yang telah dibiayai masih belum maksimal. Selain itu, terdapat pemikiranpemikiran nasabah yang berasumsi bahwa pada bank syariah berlaku akad bagi hasil dan bagi rugi sehingga nasabah tidak ingin memaksimalkan usahanya untuk memperoleh keuntungan. Ketika pengelolaan usaha nasabah tidak dilakukan dengan baik dan tidak 
mendapatkan keuntungan maksimal, maka nasabah akan sulit memenuhi kewajiban pembayaran pada bank. Terlebih jika nasabah mengalami kegagalan usaha, maka bank akan turut menanggung kerugian dari modal yang berikan.

\section{Resiko Likuiditas}

Data tabel diatas tampak bahwa untuk bank syariah mempunyai nilai rata-rata rasio FDR (resiko likuiditas) sebesar 84,20\%, sedangkan pada bank konvensional menunjukkan angka rata-rata rasio LDR (resiko likuiditas) sebesar 85,34\%. Nilai rerata pada bank konvensional lebih besar dari pada bank syariah. Hal ini dapat dikatakan kondisi atau kemampuan bank konvensional relatif tidak likuid karena persentase yang lebih besar pada tahun 2014-2018. Menurut Hidayah (2018) nilai LDR yang semakin tinggi menunjukkan bahwa bank mampu secara maksimal memanfaatkan likuiditas yang dimiliki untuk menyalurkan kredit, peningkatan penyaluran kredit ini tentunya juga akan meningkatkan profitabilitas dengan bertambahnya pendapatan operasional bank. Sebaliknya, nilai LDR yang terlalu rendah menunjukkan bahwa bank terlalu berhati-hati dalam pemanfaatan likuiditas untuk penyaluran kredit, sehingga kredit yang disalurkan tidak maksimal, rendahnya tingkat penyaluran kredit tentunya akan membuat profitabilitas bank juga rendah.

\section{Resiko Operasional}

Berdasarkan tabel diatas, diketahui nilai memiliki selisih 24/ 26 dan bank syariah memiliki rata-rata rasio yang cenderung lebih besar. Tingginya rasio BOPO pada bank syariah disebabkan karena saat ini bank syariah termasuk bank yang baru dan masih berkembang untuk dapat memberikan layanan yang lebih baik untuk masyarakat atau calon nasabah maka bank syariah memerlukan biaya operasional yang besar. Jumlah kantor bank syariah yang masih terbilang sedikit dan sistem yang digunakan masih jauh tertinggal dibandingkan dengan bank konvensional, sehingga sangat membutuhkan biaya operasional tinggi untuk memperluas pasar. Perkembangan bank konvensional yang lebih dulu menjamur di masyarakat membuat bank konvensional dalam melakukan kegiatan operasionalnya dan meminimalisir resiko dapat dikatakan lebih efektif dibanding bank syariah.

\section{Resiko Pasar}

Data rata-rata rasio pada tabel diatas diketahui nilai ra ta-rata NIM/NOM antara bank konvensional dan bank syariah memiliki selisih 2,94 yang mana rasio NIM pada bank konvensional lebih besar. Artinya, kedua bank yang menjadi objek penelitian ini adalah aman, dikarenakan rasio NIM atau NOM masih bertanda positif.

\subsection{Hasil uji normalitas}

Penulis melakukan uji normalitas data untuk mengetahui apakah data yang dijadikan penelitian ini normal atau tidak, menggunakan metode Kolmogorof Smirnov jika diketahui hasil nilai signifikansi > 0,05 maka data terdistribusi normal (Ghozali, 2016). 
Tabel 2. Hasil uji normalitas data Bank Konvensional

\begin{tabular}{ccl}
\hline Indikator Rasio yang diuji & Nilai Sig (2-tailed) & Keterangan \\
\hline NPL & 0,801 & Normal \\
LDR & 0,569 & Normal \\
BOPO & 0,969 & Normal \\
NIM & 0,572 & Normal \\
\hline
\end{tabular}

Berdasarkan tabel 2 diatas, tampak bahwa nilai dari semua indikator untuk bank konvensional $>0,05$, sehingga dapat disimpulkan bahwa data telah terdistribusi secara normal. Untuk proses uji beda selanjutnya dapat menggunakan metode uji beda t-test independent sample.

Tabel 3. Hasil uji normalitas data Bank Syariah

\begin{tabular}{ccc}
\hline Indikator Rasio yang diuji & Nilai Sig (2-tailed) & Keterangan \\
\hline NPF & 0,799 & Normal \\
FDR & 0,786 & Normal \\
BOPO & 0,952 & Normal \\
NOM & 0,048 & Tidak normal \\
\hline
\end{tabular}

Berdasarkan tabel 3 diatas, tampak bahwa nilai signifikansi dari 3 indikator untuk bank syariah NPF, FDR dan BOPO > 0,05, sehingga dapat dikatakan bahwa data sudah terdistribusi normal. Namun, untuk nilai signifikasi pada indikator NOM sebesar 0,048 (< $0,05)$, tidak terdistribusi secara normal, sehingga untuk proses uji beda selanjutnya perlu menggunakan metode Mann Whitney.

Tabel 4. Hasil Uji Beda independent sample t-test

\begin{tabular}{lllll}
\hline \multicolumn{1}{c}{ Indikator } & $\mathrm{F}$ & $\mathrm{Sig}$ & $\mathrm{t}$ & $\mathrm{Sig}$ \\
\hline NPF/NPL & 10,862 & 0,002 & $-1,944$ & 0,063 \\
FDR/LDR & 3,198 & 0,082 & 0,630 & 0,532 \\
BOPO & 1,099 & 0,301 & $-15,513$ & 0,000 \\
NIM/NOM & Menggunakan uji beda Mann Whitney & 0,006 \\
\hline
\end{tabular}

\section{Resiko kredit}

Berdasarkan tabel 4 diatas menunjukkan bahwa nilai sig pada $\mathrm{F}$ hitung $=0,002(<0,05)$ sehingga data uji t yang digunakan adalah equal not assumed, dimana nilai $\mathrm{t}=-1,944$ dengan nilai signifikansi 0,063 (>0,05), maka dapat ditarik kesimpulan dari penelitian ini bahwa tidak terdapat perbedaan dilihat dari resiko kredit (rasio NPF/NPL). Hasil penelitian ini mendukung penelitian Fitriana et al., (2015). Kemungkinan resiko yang dihadapi bank syariah relatif sama dengan bank konvensional karena sebagian besar kegiatan yang dilakukan, baik itu proses bisnis, peraturan, maupun pengelolaan resiko dalam bank syariah masih mengacu pada bank konvensional sehingga tidak terjadi perbedaan yang signifikan diantara keduanya. 


\section{Resiko likuiditas}

Tabel 4 diatas, menunjukkan bahwa nilai sig pada $\mathrm{F}$ hitung $=0,082(>0,05)$ sehingga data uji t yang digunakan adalah equal assumed, dimana nilai $\mathrm{t}=0,630$ dengan sig 0,532 (>0,05), maka dapat disimpulkan bahwa tidak terdapat perbedaan dilihat dari resiko likuiditas (rasio FDR/LDR). Hasil penelitian ini mendukung penelitian Fitriana et al (2015). Sama halnya dengan yang terjadi pada resiko kredit, bank syariah masih mengacu atau berpedoman pada bank konvensional karena diatur dan diawasi oleh Otoritas Jasa Keuangan yang bersifat umum dan tidak mengkhususkan aturan untuk perbankan syariah, sehingga tingkat resiko likuiditas bank syariah tidak berbeda signifikan dengan tingkat resiko likuiditas di bank konvensional.

\section{Resiko operasional}

Tabel 4 diatas menunjukkan bahwa nilai sig pada $\mathrm{F}$ hitung $=0,301(>0,05)$ sehingga dari data uji t yang digunakan adalah equal assumed, dimana nilai $\mathrm{t}=-15,513$ dengan nilai signifikansi 0,000 $(<0,05)$, maka dapat ditarik kesimpulkan pada penelitian ini bahwa terdapat perbedaan dilihat dari resiko operasional (rasio BOPO). Rata-rata BOPO bank syariah lebih besar dibandingkan dengan bank konvensional yaitu 92,08\% > 67,82\%. Angka ini menunjukkan bahwa bank syariah lebih efisien dalam menggunakan biaya operasional meskipun pada dasarnya BI telah menentukan batas atau standar BOPO yang baik pada angka 92\% sehingga pada penelitian ini kedua bank tersebut masih dalam kondisi yang ideal. Hasil penelitian ini didukung oleh Jahja dan Iqbal (2012) yang menyatakan BOPO bank syariah lebih besar dibandingkan konvensional yaitu 78,94\% > 64,81\% dan Rindawati (2007) yaitu $85,61 \%>70,65 \%$.

\section{Resiko pasar}

Berdasarkan hasil uji normalitas, data pada resiko pasar tidak normal, maka pengujian hipotesis menggunakan metode Mann Whitney. Berdasarkan uji beda Mann Whitney, menunjukkan bahwa nilai signifikansi $=0,006(<0,05)$ sehingga dapat ditarik kesimpulkan pada penelitian ini bahwa terdapat perbedaan dilihat dari resiko pasar yang ditunjukkan dengan rasio NIM dan NOM. Perbedaan bank konvensional dan bank syariah disebabkan karena bank konvensional lebih dipengaruhi oleh tingkat suku bunga sehingga mampu menghasilkan pendapatan bunga yang semakin besar dari aktiva produktifnya, sedangkan bank syariah tidak mengenal adanya bunga namun dipengaruhi oleh perubahan nilai tukar. Hal ini ditunjukkan dari hasil olah data yaitu nilai rata-rata NIM pada bank konvensional sebesar 6,56 lebih besar dari NOM bank syariah yaitu 3,62. Hasil penelitian ini juga sesuai dengan teori serta ketetapan oleh Bank Indonesia, yaitu besarnya NIM yang harus dicapai oleh suatu bank adalah di atas 6\% agar dapat mempengaruhi kinerja keuangan perbankan itu sendiri. Hasil penelitian ini didukung oleh penelitian yang dilakukan oleh Arinta (2016) yang menyatakan bahwa terdapat perbedaan resiko pasar dilihat dari rasio NIM pada bank konvensional dan rasio NOM pada bank syariah yang menggunakan sampel Bank Mandiri Syariah dengan Bank Mandiri pada tahun 2012-2015. Dayu (2015) juga menyatakan kemampuan manajemen bank dalam mengelola aktiva produktif untuk menghasilkan 
pendapatan bunga bersih semakin besar maka akan meningkatkan pendapatan bunga atas aktiva produktif yang dikelola bank.

\section{Kesimpulan, keterbatasan, dan saran}

Berdasarkan hasil uji hipotesis yang dilakukan dapat disimpulkan bahwa tingkat resiko kredit dengan indikator NPF dan resiko likuiditas dengan indikator rasio LDR tidak terdapat perbedaan yang signifikan antara bank konvensional dan bank syariah. Hal ini dapat diartikan bahwa kedua bank baik bank konvensional dan bank syariah dapat menekan atau meminimalisir resiko kredit maupun resiko likuiditas dengan baik. Bank Indonesia telah menetapkan batas normal rasio NPL dan NPF yaitu $<5 \%$, sedangkan untuk rasio LDR Bank Indonesia yaitu sebesar $85 \%-100 \%$. Untuk rasio BOPO dan NIM yang mewakili resiko operasional dan resiko pasar berdasarkan uji hipotesis terdapat perbedaan. Perbedaan resiko operasional ini terjadi karena saat ini bank syariah masih tergolong baru maka bank syariah lebih banyak mengeluarkan beban operasionalnya untuk kepentingan menambah produk dan fasilitas, dibandingkan dengan bank konvensional yang lebih dulu berdiri. Perbedaan resiko pasar karena bank konvensional lebih dipengaruhi oleh tingkat suku bunga sehingga mampu menghasilkan pendapatan bunga yang semakin besar dari aktiva produktifnya sedangkan untuk bank syariah hanya dipengaruhi oleh nilai tukar saja.

Penelitian ini masih banyak terdapat kekurangan dikarenakan keterbatasan peneliti, yaitu hanya mengutamakan pada resiko keuangan untuk menilai kinerja keuangan bank, indikator yang digunakan hanya 4 indikator, yaitu NPL, LDR, BOPO, dan NIM pada bank konvensional dan NPF, FDR, BOPO, dan NOM untuk bank syariah. Obyek yang peneliti gunakan adalah bank konvensional dan bank syariah yang masih memiliki hubungan afiliasi.

Saran untuk penelitian selanjutnya dapat mengembangkan indikator dan objek penelitian agar mendapatkan data sekaligus fakta yang lebih nyata dari sampel kedua bank. Selain itu dengan memperluas variabel lain yang dapat mengukur kinerja keuangan bank seperti CAR, ROA, dan ROE.

Hasil penelitian ini berdampak baik pada pihak manajemen bank syariah maupun bank konvensional supaya dapat melakukan manajemen resiko keuangan bank lebih baik dengan cara meminimalisir pemberian kredit atau pembiayaan besar dengan jangka panjang. Kedua jenis bank diharapkan dapat menjaga dan menyeimbangkan rasio keuangan masing-masing agar kinerja keuangan perusahaan meningkat.

\section{Daftar Pustaka}

Arinta, Y. N. (2016). Analisis perbandingan kinerja keuangan antara Bank Syariah dan Bank Konvensional (Studi kasus pada Bank Syariah Mandiri dan Bank Mandiri). Muqtasid: Jurnal Ekonomi dan Perbankan Syariah, 7(1), 119-140.

Dayu, P. Q. (2015). Pengaruh tingkat kecukupan modal, likuiditas, resiko pasar, dan resiko kredit terhadap kinerja keuangan pada Bank Konvensional. Jurnal Ilmiah Mahasiswa, $3(1)$

Fitriana, N., Rosyid, A., Fakhrina, A. (2015). Tingkat kesehatan Bank BUMN Syariah dengan Bank BUMN Konvensional: Metode RGEC (Risk Profile, Good Corporate Governance, Earning, Capital). Jurnal Ekonomi dan Bisnis, 17(2), 1-15 
Ghozali, I. (2016). Aplikasi Analisis Multivariat dengan Program IBM SPSS 23, Edisi Delapan. Penerbit Universitas Diponogoro. Semarang.

Hidayah, N. (2018). Pengaruh efisiensi operasional, resiko kredit, dan resiko likuiditas terhadap profitabilitas (Studi Pada Bank Pembangunan Daerah Konvensional di Indonesia Periode Tahun 2013-2017). Jurnal Ilmiah Mahasiswa FEB Universitas Brawijaya, 7(2).

Iskandar, S. (2013). Bank dan Lembaga Keuangan Lainnya. Jakarta: In Media.

Jahja, A. S. \& Iqbal, M. (2012). Analisis perbandingan kinerja keuangan Perbankan Syariah dengan Perbankan Konvensional. Episteme, 7(2),337-360

Latumaerissa, J. R. (2014). Manajemen Bank Umum. Jakarta: Mitra Wacana Media.

Lombogia, R. (2015). Analisis komparasi kinerja keuangan berdasarkan resiko kredit, resiko pasar, resiko likuiditas, dan liquidity coverage ratio (Studi Kasus pada Bank BUMN Go Public Sebelum dan Sesudah Pemberlakuan OJK). Jurnal EMBA: Jurnal Riset Ekonomi, Manajemen, Bisnis dan Akuntansi, 3(3). 798-806

Lukman, D. (2009). Manajemen Perbankan. Jakarta: Ghalia Indonesia.

Mawardi, W. (2004). Analisis faktor-faktor yang mempengaruhi kinerja keuangan Bank Umum di Indonesia. Tesis Program MM Undip tidak dipublikasikan.

Nainggolan, H. (2017). Analisis resiko keuangan dengan Model Altman Z-Score pada Perusahaan Perbankan di Indonesia (Listed di Bursa Efek Indonesia). Jurnal Ilmiah Akuntansi dan Keuangan, 6(2), 96-115.

Putri, Y. F., Fadah, I., \& Endhiarto, T (2015). Analisis perbandingan kinerja keuangan Bank Konvensional dan Bank Syariah. Jurnal Ekonomi Akuntansi dan Manajemen, 14(1), 27-42.

Ramlan, S. R., Moniharapon, S., \& Tulung, J. E. (2018). Analisis perbandingan resiko kredit antara Bank Syariah dan Bank Konvensional. Jurnal EMBA: Jurnal Riset Ekonomi, Manajemen, Bisnis dan Akuntansi, 6(1), 151-160

Rustam, B. R. (2013). Manajemen Resiko Perbankan Syariah di Indonesia. Jakarta: Salemba Empat.

Taswan (2017). Akuntansi Perbankan Transaksi dalam Valuta Rupiah. Yogyakarta: UPP STIM YKPN

Usman, B. (2003). Analisis rasio keuangan dalam memprediksi perubahan laba pada BankBank di Indonesia. Media Riset Bisnis \& Manajemen 3(1), 59-74

Yulianti, R. T. (2009). Manajemen resiko perbankan Syariah. Jurnal Ekonomi Islam La Riba $3(2), 36-53$

www.idx.co.id 